\title{
Investigating the Influence of Technology Inflows on Technology Outflows in Open Innovation Processes: A Longitudinal Analysis*
}

\author{
Uros Sikimic, Vittorio Chiesa, Federico Frattini, and Vittoria G. Scalera
}

The open innovation (OI) paradigm emphasizes the importance of integrating inbound and outbound flows of technology to increase a firm's innovation performance. While the synergies between technology inflows and outflows have been discussed in conceptual OI articles, the majority of empirical studies have typically focused on either the inward or the outward dimension of OI. According to recent reviews of OI literature, there is a need for further research that takes an integrated perspective on this topic and studies the combination of the inbound and outbound dimensions of OI. This paper follows these calls by focusing on technology licensing as the main contractual form for OI, and by investigating the relationship between technology in-licensing and out-licensing activities at the firm level of analysis. In particular, this paper argues that technology in-licensing positively influences the volume of technology out-licensing through two mechanisms. The first-resource-based-occurs because in-licensing investments expand and enrich the firm's technology base, thus increasing its value and, as a result, creating more opportunities for out-licensing. The second - capabilities-based - occurs because, due to commonalities between technology in-licensing and out-licensing in terms of performed tasks and required skills, repeated execution of inlicensing transactions contributes to the development of higher out-licensing capabilities and, as a result, increase out-licensing volume. These arguments are tested using a panel dataset of 837 Spanish manufacturing firms over the period 1998-2007. Consistent with the predictions, the empirical analysis shows that higher investments in inlicensing and more extensive in-licensing experience lead to superior volumes of technology out-licensing. These results contribute to research on $O I$ and licensing, by empirically showing the existence of positive interactions between technology inflows and outflows and of synergies in the development of absorptive and desorptive capacities.

\section{Introduction}

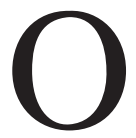

pen innovation (OI) has become a critical management model in technological innovation. It is defined as the "purposive inflows and outflows of knowledge to accelerate internal innovation, and expand the markets for external use of innovation, respectively" (Chesbrough, 2006, p. i). This definition emphasizes the importance of a bidirectional technology flow, taking place from outside to inside the firm (inbound $\mathrm{OI}$ ), and from inside to

Address correspondence to: Federico Frattini, Politecnico di Milano, Department of Management, Economics and Industrial Engineering, Piazza L. da Vinci 32 - 20133 Milano, Italy. E-mail: federico.frattini@ polimi.it. Tel.: +390223992796.

*The authors would like to thank the editor and two anonymous reviewers of JPIM for their comments and guidance during the review process. The current version of this study has also benefited from the valuable comments offered by Mattia Bianchi and Samuele Murtinu. The usual caveat applies. outside the firm (outbound OI). Through inbound OI, a firm accesses discoveries and technologies of others and integrates them into its own innovation processes. Instead, through outbound OI a firm transfers proprietary technologies to external actors for commercial purposes (Bianchi, Cavaliere, Chiaroni, Frattini, and Chiesa, 2011; Bianchi, Chiaroni, Chiesa, and Frattini, 2011). Both inbound and outbound OI can take multiple forms (Bianchi, Croce, Dell'Era, Di Benedetto, and Frattini, 2015). Among the most frequently used, inbound OI includes mergers and acquisitions, joint ventures, and in-licensing. Outbound OI entails spinoffs, technology sale, inter-organizational collaborations, and out-licensing (Lichtenthaler, 2005).

Prior studies in OI research have typically focused on technology flows occurring in a single direction. The majority of these studies have considered inbound OI as the focus of their analysis (Laursen and Salter, 2006; Leone and Reichstein, 2012), and only a few of 
them have explored outbound OI (Bianchi, Campodall'Orto, Frattini, and Vercesi, 2010; Lichtenthaler and Ernst, 2007). An integrated view of both OI dimensions, which Enkel, Gassmann, and Chesbrough (2009) name "coupled process" in OI, has instead received far less attention. Coupled OI processes entail a two-way interaction between the focal firm and external sources of technology, whereby the focal firm makes a combined use of both technology inflows and outflows. Firms aiming to maximize the returns from their R\&D investments are thus suggested to act both as buyers and sellers in the expanding markets for technologies (Arora, Fosfuri, and Gambardella, 2001). This paper examines whether and how technology inflows have an impact on technology outflows.

To the best of our knowledge, only two recent studies have investigated inbound and outbound OI jointly.

\section{BIOGRAPHICAL SKETCHES}

Dr. Uros Sikimic is R\&D Manager at 3Lateral, a highly innovative company specialized in digitalization of humans. His main research areas focus on open innovation and business models. He has published several articles in journals such as Journal of Product Innovation Management, Journal of Business Chemistry, Actual Problems of Economics, and Agricultural Economics.

Dr. Vittorio Chiesa is full professor at the Department of Management, Economics and Industrial Engineering at Politecnico di Milano, where he is member of the Board, responsible for the Technology Strategy area at MIP (the Graduate School of Business of Politecnico di Milano), and director of the Executive Master in Energy Management. He has been visiting researcher at the London Business School. His main research areas are in the fields of $R \& D$ and innovation management, evaluation of intangible assets, and creation of start-ups in science based industries. He is author of six books and more than 200 international publications. He was in the list of the Top 60 World's Innovation Management Scholars in the period 1991-2010.

Dr. Federico Frattini is associate professor at the Department of Management, Economics and Industrial Engineering at Politecnico di Milano, where he is also director of the MBA \& Executive MBA programs. He is honorary researcher at Lancaster University Management School and, in 2013, was nominated among the top 50 authors worldwide in Innovation and Technology Management by IAMOT, the International Association for Management of Technology. His research interest is in innovation and technology management. On these topics, he has written more than 160 books, chapters in edited books, and articles in international journals such as Academy of Management Perspectives, Journal of Product Innovation Management, California Management Review, and many others.

Dr. Vittoria G. Scalera is assistant professor at the Amsterdam Business School, University of Amsterdam, and she has been visiting scholar at the Fox School of Business, Temple University. Her research mainly focuses on international business and innovation management. Her studies appear or are forthcoming in Journal of International Management, Multinational Business Review, and Advances in International Management, among others.
Hung and Chou (2013) find that the interaction between inbound and outbound OI positively influences the firm's financial performance. Cassiman and Valentini (2015) show that organizations that engage simultaneously in buying and selling technologies enjoy larger sales of new products, but at the expense of a more than proportional increase in $R \& D$ costs. While these two studies examine the joint effect of technology inflows and outflows on a firm's overall economic and financial performance, they do not explore whether a relationship exists between the two flows and what form it takes.

The same limitation applies to the vast stream of research on R\&D alliances. Studies in this field explore how firms improve their innovation performance by engaging in strategic $R \& D$ alliances. These studies show that $R \& D$ alliances have a positive influence on the innovation outputs and competitive advantage of the firms involved in these interorganizational relationships (Jiang and Li, 2009; Mowery, Oxley, and Silverman, 1996; Stuart, 2000), with issues like physical and cultural proximity of technology sources (Capaldo and Messeni Petruzzelli, 2015; Coff, 2003; Ganesan, Malter, and Rindfleisch, 2005; Lane and Lubatkin, 1998; Reuer and Lahiri, 2014; Sampson, 2007), organization and management models for R\&D alliances (Capaldo and Messeni Petruzzelli, 2015; Uzzi, 1997) and R\&D alliance experience (Capaldo and Messeni Petruzzelli, 2011; Hoang and Rothaermel, 2005; Sampson, 2005) determining the intensity of the innovation gains. R\&D alliances research aims to explain under what conditions the inter-organizational technology flows taking place between the firms involved in the R\&D alliance drive superior innovation outputs. However, it does not explain how and through what mechanisms inbound and outbound technology flows influence each other. For this reason, R\&D alliances research typically overlooks the interplay between the two technologies flows, inside and outside the focal firm.

This paper attempts to fill this gap by empirically investigating the influence of technology inflows on technology outflows at the firm level. Technology flows represent a particular form of knowledge flows (as illustrated by Easterby-Smith, Lyles, and Tsang, 2008). This paper focuses on technology flows only, in the form of technology licensing. Technology licensing is defined as a "transfer of technology by means of a contract of industrial property rights" (Guadamuz, 2005 , p. 591). Licensing agreements can include also contractual agreements for the use of trademarks, 
service marks, and copyrights (Woznick, 1996), but none of these forms of licensing are the focus of this study. Through in-licensing, firms acquire (the rights to use) technologies developed by external organizations and therefore realize inbound OI. Instead, through out-licensing, firms commercialize (the rights to use) internal technologies to outside partners, thereby realizing outbound OI. These transactions allow technology inflows and outflows to take place, respectively.

Examining technology licensing, rather than R\&D alliances or other forms for OI, allows us to separately consider the inbound and outbound dimensions of technology flows. In particular, the formalized nature of licensing agreements allows capturing the direction, amount, and value of technology exchange between the focal firms and external actors. By tracking licensing in- and out-payments, it is possible to assign a measure of quantity and quality to the technology exchanged, which represents a contribution of this study. Moreover, licensing has become increasingly popular as a form for OI. Firms' increasing propensity to activate licensing agreements prompted some scholars to talk about a "pro-licensing era" (Granstrand, 2004), as the value of these transactions worldwide has approached US $\$ 100$ billion annually (Athreye and Cantwell, 2007). This growth is, however, not equally distributed among firms. For instance, regarding outlicensing, the above-mentioned growth is the consequence of the increase of licensing business in a minority of already active licensors, with the remaining companies failing to realize significant monetary returns from outbound OI (Lichtenthaler and Ernst, 2007).

Does technology in-licensing play a role in explaining these large differences across firms in terms of volume of technology out-licensing? To answer this research question, this paper distinguishes between two potential effects of in-licensing on out-licensing volume. The first is related to the amount and quality of the technologies in-licensed. Using arguments from the resource-based view of the firm (Barney, 1991), this paper argues that larger investments in inlicensing result in higher volumes of revenues from out-licensing. The rationale is that inbound OI helps a firm expand and enrich its technology portfolio, making it more attractive to external organizations and thus leading to higher levels of outbound OI. This view is consistent with prior studies conceptualizing patents and the underlying technologies exchanged through licensing agreements as resources (Markman,
Espina, and Phan, 2004; Schilling and Steensma, 2002). The second is related to prior experience in inlicensing deals. Drawing on the capabilities-based perspective (Lichtenthaler and Lichtenthaler, 2009) and on a recent study elaborating on the benefits of licensing experience (Bianchi and Lejarraga, 2016), the present study proposes that, due to commonalities between inbound and outbound $\mathrm{OI}$ in terms of performed tasks and required skills, repeated execution of in-licensing transactions contribute to the development of outlicensing capabilities and, as a result, to higher outlicensing volumes of revenues.

The conceptual framework of this paper is tested using a panel data set of 837 Spanish manufacturing firms observed during a 10-year time frame (from 1998 to 2007). The longitudinal nature of the present analysis allows to take into account the delays between technology creation and exploitation, which can be particularly long in technological innovation processes (Ahuja and Katila, 2001; Sampson, 2005). The findings support the existence of a 2-year time lag before technology inflows originating from in-licensing have an impact on the outflows enabled by technology outlicensing. Moreover, the empirical analysis shows that both investments and experience in in-licensing positively influence the volume of out-licensing.

The present study provides a number of contributions to innovation research, from both a theoretical and an empirical point of view. First, it sheds more light on the "coupled process" in OI (Enkel et al., 2009), providing original insights on the two-way interaction model involving simultaneously technology inflows and outflows between the focal firm and external sources of technology. Second, this paper offers new contributions to technology licensing research by focusing on the relationship between inward and outward technology flows, and analyzing the effects of in-licensing determinants on out-licensing volume. Third, the study extends the understanding of technology creation and exploitation processes by adopting a capability-based perspective. In particular, it complements existing research by providing additional support to the existence of a time span between the acquisition of external technology and the ability of the firm to understand, absorb, and transform it, in order to ultimately generate new knowledge (Lane, Koka, and Pathak, 2006). Finally, the use of a "distributed lags" empirical procedure represents one the first attempts in OI research to analyze the presence of a time delay that may occur between technology inflows and outflows. 
The paper proceeds as follows. In the next section, it provides a review of the literature on technology inlicensing and out-licensing and introduces the research hypotheses. Then, the empirical sections describe the dataset and the methodology, and present the results of the econometric estimates. Finally, a discussion of the main findings, in terms of theoretical and managerial contributions, concludes the paper.

\section{Research Hypotheses}

An important contribution of OI research to prior innovation studies, such as those focused on absorptive capacity or user-driven innovation (Cohen and Levinthal, 1990; von Hippel, 1986), is the explicit integration of inbound and outbound technology flows (Lichtenthaler, 2011). While the relationship that exists between technology inflows and outflows is emphasized in theoretical OI research (Chesbrough, 2003; Enkel et al., 2009; Lichtenthaler and Lichtenthaler, 2009), it has received very limited empirical attention. Some exceptions are reviewed hereafter. Walter (2012) investigates both in-licensing and out-licensing transactions and their distinct potential to generate superior stock market returns, but he does not examine the anatomy of the interactions between the two OI modes. Studies on cross-licensing (see, among the others, Grindley and Teece, 1997) document the existence of bi-directional technology flows among partners, which are simultaneously technology buyers and sellers in the context of a single licensing deal. The birth and diffusion of markets for ideas allow firms to more easily adopt coupled OI processes, by buying and selling ideas and technologies at the same time, playing the roles of seekers and solvers (Natalicchio, Petruzzelli, and Garavelli, 2014). Adopting a firm-level perspective, Lichtenthaler (2008) and van de Vrande, de Jong, Vanhaverbeke, and de Rochemont (2009) perform a cluster analysis showing that firms that combine inbound and outbound OI enjoy a higher operating margin than those companies that have opened their innovation processes only in one direction. In these articles, balanced open innovators are those firms that engage in coupled OI processes. Results by Hung and Chou (2013) and, although to a smaller extent, by Cassiman and Valentini (2015) highlight the economic benefits from pursuing a two-sided approach to OI. However, while these studies focus on the joint effects of technology inflows and outflows on the firm's overall performance, they do not examine the influence of one flow on the other. Considering the attention recently paid by scholars and managers to understanding the drivers of superior out-licensing performance, this issue appears particularly timely and important. Therefore, this paper provides a detailed investigation of the impact of in-licensing on out-licensing volume. In the following, it argues that this impact may depend on the size of in-licensing investments and on the extent of in-licensing experience.

In doing so the theoretical framework relies on both the resource-based view of the firm (Barney, 1991) and the capability-based perspective (Lichtenthaler and Lichtenthaler, 2009). The combination of these two theories enables us to analyze in depth the complex mechanisms behind technology out-licensing and its dynamic interaction with in-licensing activities. As such, technology out-licensing volume is the result of two interconnected determinants, i.e., the technology portfolio of the firm and its ability to exploit it on the market for technologies.

As in-licensing is one of the most efficient ways enabling companies to source external technology, it is part of the resources creation process at the basis of the competitive advantage of the firm. Technology acquired through in-licensing can enrich or complement the technology portfolio of the focal firm and, therefore, increase the internal resources available for the generation of new technology, in line with the resource-based view (Bianchi et al., 2015).

However, out-licensing volume produced by a firm may be influenced not only by the size and quality of its technology basis, but also by its ability to effectively activate and manage transactions in the market for technologies. Given the high transaction costs involved in technology trade (Arora and Gambardella, 2010), the quality of the technology may not be per se the only determinant of the out-licensing volume, but-other things being equal - the possibility to leverage technology licensing-specific capabilities can reduce the uncertainty and complexity involved in the transactions. Based on a capability-based perspective, this paper suggests that the experience in related activities, such as in-licensing, enables the firm to develop such specific capabilities, which can ultimately benefit out-licensing volume (Bianchi and Lejarraga, 2016; Lichtenthaler and Ernst, 2007).

\section{The Impact of In-Licensing Investments on Out- Licensing Volume}

A resource-based perspective suggests that the volume of technology out-licensing achieved by a firm may depend on valuable, rare and difficult to imitate 
resources, such as the amount and quality of the technologies made available for commercialization (Barney, 1991; Bianchi, Frattini, Lejarraga, and Di Minin, 2014). In addition to the technology generated inside the firm, typically within its R\&D unit, a firm's technology basis can be expanded and enriched through the acquisition of technologies from external sources (see Bianchi et al., 2015).

In-licensing is a form through which external technology acquisition may be implemented and therefore it may feed the technology portfolio of a firm with novel technologies from close or distant fields (Rigby and Zook, 2002). The current rapid technological progress and convergence require companies to build and maintain expertise in multiple technology domains (Grant, 1996). In-licensing is a suitable method through which firms gain access to the latest technological developments wherever they occur (Laursen and Salter, 2006), thus fighting competency traps and inertia (Levinthal and March, 1993). Laursen, Leone, and Torrisi (2010) find that firms that rely on inlicensing perform a wider exploration of the technological landscape-more distant from their existing technological portfolio-compared with firms that do not in-license.

Technology acquired from external sources can then be recombined with internal assets and create original and difficult-to-imitate resource configurations, whose aggregated value is greater than the individual worth of each single asset (Flemming and Sorenson, 2004; Kogut and Zander, 1992). The broader variety of technology portfolios achieved by firms that intensely invest in in-licensing enables the generation of a larger number of technology combinations, which may represent valuable out-licensing opportunities as the firm looks for external partners to complete their development and to commercialize the resulting products (Bianchi et al., 2014). A notable example of this mechanism is the approach to innovation adopted in Procter \& Gamble (Brown and Anthony, 2011).

In-licensing also provides firms with a time advantage, as it speeds up the invention process (Markman, Gianiodis, Phan, and Balkin, 2005). This occurs by avoiding repetition of R\&D tasks as well as by focusing internal R\&D resources on fewer and probably more complex innovation problems (Leone and Reichstein, 2012). Rapid processes are particularly important in technological innovation today, where knowledge capital depreciates sharply, losing significant value in few years (Ahuja and Katila, 2001). In-licensing thus contrasts the decay of the value of the technology portfolio, maintaining its attractiveness to external partners.

In-licensing also contributes to the reduction of the level of R\&D risks. In-licensed technologies are typically at an advanced stage of development and have better proven performance (Atuahene-Gima, 1993; Roberts and Berry, 1984). A technology portfolio characterized by a lower level of uncertainty can facilitate the accomplishment of out-licensing deals. Indeed, uncertainty about the value of technology, which is an intangible, idiosyncratic, and predominantly tacit good, is a key barrier to technology trade and to the development of markets for technologies (Arora and Gambardella, 2010).

In light of the above arguments, this paper suggests that firms with larger investments in in-licensing develop a more valuable and attractive technology basis that, in turn, translates into a higher volume of out-licensing. Thus the following hypothesis is presented:

\section{H1: Firms with larger in-licensing investments achieve higher out-licensing volume.}

\section{The Impact of In-Licensing Experience on Out- Licensing Volume}

The development of capabilities is cumulative and dependent on past experience (Teece, Pisano, and Shuen, 1997). Repeated engagements in the focal activity, in this case licensing, activate an organizational learning process (Levitt and March, 1988). This process implies the adaptation of existing routines, the interpretation of past actions, and of their effective implementation as a basis for current and future actions and processes (Fiol and Lyles, 1985). The iteration of "doing, learning, and doing some more" allows the creation, retention, retrieval, and use of essential knowledge that enables firms to perform licensing activities in improved ways. Although involving the same contractual form, the managerial challenges of in-licensing and out-licensing may be different. For the former process, it is critical to identify suitable technologies in the external landscape, whereas the latter process requires searching for profitable market applications for the firm's own technologies (Lichtenthaler, 2011). However, the nature of the licensing process points to the existence of several commonalities between in-licensing and out-licensing. Although they are executed in the opposite direction, 
the processes of acquiring and commercializing technology through licensing require the execution of similar activities, such as technology and market intelligence, partner selection, technology transfer and contract monitoring, and the ownership of equivalent skills of technical and legal nature, such as in intellectual property valuation and negotiation (Lichtenthaler and Lichtenthaler, 2009).

Many firms have recently implemented organizational changes by establishing licensing departments that are responsible for both buying and selling technologies. This may be related to the complementary capabilities necessary to both acquire and sell technology, and so employers simultaneously involved in inand out-licensing become more experienced in their job by alternatively sitting on both sides of the table (Bidault and Fischer, 1994). When instead firms manage inbound and outbound OI as stand-alone activities, by handing the former over to the R\&D function and the latter to the legal department without coordination, they forego these synergies (Lichtenthaler and Lichtenthaler, 2010). As a result, leading open innovators international companies, such as Procter \& Gamble, IBM, and Cisco have developed an organizational structure aimed at balancing inbound and outbound technology transfer, achieving a co-evolution of capabilities and transaction costs based on learning effects in the market for technologies (Jacobides and Winter, 2005).

Moreover, prior research has found that companies that take advantage of technology acquisition more frequently engage in revenue-generating licensing transactions, thus acting as brokers in their networks (Lowe and Taylor, 1998; Stuart, Ozdemir, and Ding, 2007). Employing a complementary perspective, and focusing on out-licensing experience, Bianchi and Lejarraga (2016) find that prior experience in out-licensing positively affects licensing revenues at a decreasing rate. They report that the effect of out-licensing experience on licensing revenues is strengthened in companies with a higher proportion of workforce endowed with advanced skills, whereas it is reduced in companies with a higher proportion of low-skilled employees. The findings of these studies may suggest positive synergies between the capabilities required to proficiently execute in- and out-licensing, like absorptive and desorptive capacity, respectively.

Based on these elements, this study argues that repeated execution of in-licensing transactions may thus generate useful expertise that can be leveraged for successfully initiating and concluding out-licensing deals. Greater in-licensing experience also provides a firm with external visibility and market exposure, which may foster market pull effects, reduce transaction costs, and ultimately facilitate the accomplishment of out-licensing deals at favorable conditions (Lichtenthaler and Ernst, 2007). As a consequence of their embeddedness in the markets for technologies, frequent licensee firms can collect information on licensing opportunities from their technology suppliers and develop a reputation as a reliable partner, whose collaborative behavior can be traced over multiple transactions.

Therefore, the following hypothesis is presented:

H2: Firms with more extensive in-licensing experience achieve higher out-licensing volume.

\section{Sample and Method}

\section{Data}

The hypotheses are tested using data originating from the Spanish Business Strategy Survey (SBSS), an annual survey on a representative sample of Spanish manufacturing firms. The survey was conducted by the SEPI Foundation, and financed by the Spanish Ministry of Industry, Tourism and Commerce. ${ }^{1}$ This dataset complements information about Spanish industry from the "Industrial Survey" of the National Institute of Statistics (offering aggregate information at a sectoral level), and the "Central of Balances" of the Bank of Spain (providing information about financial activities of companies).

The dataset includes a population of manufacturing companies with more than 10 employees in the year when the survey was launched (1990), observed during the period 1998-2007. As the dataset collects data from 1998 to 2007, it can include also firms with less than 10 employees, as they could have left the company in the years between the launch of the survey (1990) and 1998. The sample is widely representative of the population of the firms in industrial Spanish sectors, as it follows both the exhaustive and random sampling criteria. Moreover, the questionnaire was sent to all firms with more than 200 workers and to a random sample of firms with less than 200 workers, but more than 10 workers.

This survey has been extensively used for other empirical studies in innovation, as it provides fine-

\footnotetext{
${ }^{1}$ More detailed information of the survey is available at www.funep.es. See Ben-
} eito (2003) for a detailed description of the data. 
grained information about $R \& D$ and innovative activities at the firm level, and it represents one of the most comprehensive statistical sources about the Spanish manufacturing industry. Different versions of the dataset have been used in other studies on innovation (see, among the others, Beneito, 2003, 2006; Bianchi and Lejarraga, 2016; Bianchi et al., 2014; Kotlar, De Massis, Frattini, Bianchi, and Fang, 2013; Un, 2015). The focus on the manufacturing sector is particularly valuable in the context of the present research, because manufacturing organizations do not rely on outlicensing as their only technology exploitation mode, like some nonmanufacturing organizations do (technology transfer offices of research centers or universities, innovation intermediaries, and patent trolls). Manufacturing firms may decide whether to exploit their technologies internally, through new product development, or externally, by means of out-licensing. For this reason, the sample of manufacturing firms helps us to explore how technology in-licensing impacts technology out-licensing, in a setting where the latter is not the only technology exploitation path. Moreover, due to the short life-cycle and fast obsolescence of their products, manufacturing companies are forced to rely more on innovations that come from external sources (Tushman and Anderson, 1986). This means that OI can take an important role in their innovation strategy. SBSS is particularly appropriate here as it reports the annual amounts of firms' in-licensing investments and out-licensing revenues, which represent the core elements of this study. As such, by controlling for the internal development of new products, the influence of in-licensing investments and experience on outlicensing volume can be better isolated. Further, as also suggested by Un (2015), Spain is a good setting to study the proposed research question because it is a developed country with a level of technology in between the most advanced and backward countries. As such, Spanish manufacturing firms are a suitable ground for research in technological innovation, because of the increasingly high investments in $R \& D$ and innovation and the relative challenges in exploiting their potential economic benefits (Bianchi et al., 2014; Griffith, Huergo, Mairesse, and Peters, 2006).

Considering that the focus of this study is on the relationship between firms' out- and in-licensing activities, from the overall dataset population it includes only the firms that report their out-licensing volume. In particular, the sample used for the analyses includes companies that report their out-licensing volume in at least 9 out of 10 years of the dataset's time span.
Thus, the empirical analysis is performed on a panel of 837 firms over the time period 1998-2007. The panel is unbalanced, as some firms stopped providing information during the sample period for several reasons, such as mergers or shutdowns. It implies that throughout the period 1998-2007 some firms are included in the panel dataset only for some years.

Table 1 shows the breakdown of the sample by industries, and the corresponding average of in-licensing investments and out-licensing volume (measured by revenues). Consistent with previous studies (see Arora and Gambardella, 2010; Arora et al., 2001), there is considerable heterogeneity across industries in the use of licensing. The data in the sample suggests that industries like chemicals, plastics, and transportation equipment exhibit higher out-licensing volume, consistently with Bianchi and Lejarraga (2016). Also, in-licensing investments have a larger value than out-licensing revenues, which is aligned with previous studies (van de Vrande et al., 2009) that find that in-licensing is a far more common OI practice than out-licensing.

\section{Variables}

Since the dataset used spans 10 years (1998-2007), all observed panel variables represented in currency amounts (Euro) are corrected to constant currency terms. By doing so, all these variables are adjusted to the comparable values. For example, one unit (Euro) of the variable in the first year of the sample (1998) weights around $36 \%$ more than one unit of the variable in the last year of the sample (2007). A similar approach has been proposed in prior panel data studies (Henderson and Cockburn, 1996; Lilien, Morrison, Searls, Sonnack, and von Hippel, 2002). ${ }^{2}$ The nominal monetary values in the dataset were deflated by using information on inflation from the Spanish National Institute for Statistics (INE), taking the first year considered in the analysis (1998) as the reference year.

Dependent variable. To measure the firm's volume of technology out-licensing, the annual revenues earned from out-licensing of technology to external organizations is used. This monetary variable has been used in previous studies on outbound OI (Bianchi et al., 2014). The measure is given in Euros, and because it is a highly skewed variable, its natural logarithm is calculated and used, as commonly done in

\footnotetext{
${ }^{2}$ This inflation-adjustment procedure is frequently used in other panel data studies because it strengthens the statistical models (Arellano and Bond, 1991).
} 
Table 1. Sample Breakdown According to Industry's Mean Volume of Technology Out-licensing and In-licensing Investments in Euros

\begin{tabular}{|c|c|c|c|}
\hline Industry & No. of Firms & $\begin{array}{l}\text { Mean Volume of Technology } \\
\text { Out-licensing }\end{array}$ & $\begin{array}{l}\text { Mean Investments in Technology } \\
\text { In-licensing }\end{array}$ \\
\hline 1. Meat products & 23 & 0 & 46.08 \\
\hline 2. Food and tobacco & 84 & $10,451.97$ & $317,636.00$ \\
\hline 3. Beverage & 11 & 0 & $52,093.59$ \\
\hline 4. Textiles and clothing & 66 & 0 & $10,926.55$ \\
\hline 5. Leather, fur, and footwear & 21 & 94.07 & 197.22 \\
\hline 6. Timber & 22 & 0 & $7,034.15$ \\
\hline 7. Paper & 31 & $1,434.91$ & $11,965.45$ \\
\hline 8. Printing & 44 & 118.50 & $5,267.15$ \\
\hline 9. Chemicals and pharmaceuticals & 57 & $111,868.00$ & $624,100.70$ \\
\hline 10. Plastic and rubber products & 53 & $218,468.45$ & $131,011.90$ \\
\hline 11. Nonmetal mineral products & 57 & $9,699.22$ & $193,823.50$ \\
\hline 12. Basic metal products & 35 & $1,291.13$ & $104,378.10$ \\
\hline 13. Fabricated metal products & 90 & 0 & $18,686.63$ \\
\hline $\begin{array}{l}\text { 14. Agricultural and industrial } \\
\text { machinery and equipment }\end{array}$ & 64 & $11,307.00$ & $42,810.03$ \\
\hline $\begin{array}{l}\text { 15. Computer products, electronics, } \\
\text { and optical }\end{array}$ & 12 & $7,054.63$ & $14,253.22$ \\
\hline $\begin{array}{l}\text { 16. Electric materials and } \\
\text { accessories }\end{array}$ & 43 & 0 & $83,309.41$ \\
\hline 17. Vehicles and accessories & 46 & $41,771.07$ & $5,356.126 .00$ \\
\hline 18. Other transport equipment & 14 & $166,502.00$ & $136,897.20$ \\
\hline 19. Furniture & 46 & 911.02 & $6,151.30$ \\
\hline 20. Other manufacturing & 18 & 0 & $73,442.54$ \\
\hline Total Mean & 837 & 29,048.60 (EUR) & $359,507.84$ (EUR) \\
\hline
\end{tabular}

other similar studies (Gambardella, Giuri, and Luzzi, 2007). This variable is named Technology Outlicensing Volume $_{(i, t)}\left(\operatorname{TOLV}_{(i, t)}\right)$.

Independent variables. The survey provides the monetary in-licensing investments made by a firm each year. In particular, this measure captures the amount of money spent to in-license technologies from external organizations. Technology in-licensing investments capture both the quantity and quality of the acquired technologies. As regards the former, larger in-licensing investments should allow a bigger number of technologies to be in-sourced. As regards the latter, larger inlicensing investments should allow the focal firm to acquire more innovative, advanced and/or proven technologies. Overall, a firm that invests more in inlicensing should enjoy more valuable additions to its technology basis, thus increasing its potential for subsequent exploitation.

Because the values of in-licensing investments are given in Euros and have a highly skewed distribution, the natural logarithm of the variable is employed. In the study the name of this variable is Technology Inlicensing Investments $\left(_{(i, t)}\left(\operatorname{TILI}_{(i, t)}\right)\right.$. This variable has been used by other studies (Beneito, 2006; Bianchi and Lejarraga, 2016) and is here applied to test H1. The methodology employed follows a "distributed lags" procedure (Ahuja and Katila, 2001), as three different time lags are introduced for the in-licensing investments variable: 1-year lag, which measures annual in-licensing investments in the year prior to the observed outlicensing volume (the dependent variable); 2-year lag, which measures annual in-licensing investments made two years prior to the observed out-licensing volume; 3-year lag, which measures annual in-licensing investments made three years prior to the observed outlicensing volume. These different lagged measures are included in separate empirical models as well as combined together in a single model. Time lags are used to account for temporal precedence: technology inflows may take some time before they actually have an effect on technology outflows.

To test H2, which deals with the influence of inlicensing experience on out-licensing volume, two slightly different but complementary variables are used. The first, Number of Years Firm In-Licensed $(i, t)$ NYFIL $_{(i, t)}$ ), counts the number of years in which each firm has engaged in in-licensing activities, prior to the observed out-licensing revenues. A similar approach has been used by Bianchi and Lejarraga (2016), but in the current study the in-licensing experience is calculated within a three-year window. By restricting the time 
period used to measure in-licensing experience to three years, it is assumed that recent experience is more relevant in affecting out-licensing than experience on inlicensing deals concluded in the more distant past. So, if in 2003 the firm has in-licensed technologies in both 2001, 2002, and 2003, the value of the variable Number of Years Firm In-Licensed in 2003 is 3. Instead, if the firm has in-licensed only in 2001 and 2003, the count variable will take the value of 2 .

The second variable used to test H2 is Firm Continuously In-Licensed $_{(i, t)}\left(\right.$ FCIL $\left._{(i, t)}\right)$, which measures instead the firm's continuous, uninterrupted, engagement in in-licensing, considering a three-year time window (as for NYFIL, the same year in which the out-licensing volume is observed and the two preceding years). It is a binary variable that takes the value of 1 if the focal firm continuously in-licensed in all three years, and the value of 0 if it did not. The rationale for including in-licensing continuity in the empirical analysis is to capture the extent to which the learning-by-doing knowledge accumulated from experience deteriorates when a firm stops performing the focal activity (namely, in-licensing) or performs it in an intermittent way.

Control variables. The control variables included enable us to better assess the effect of in-licensing investments and experience on out-licensing volume. The variable $\mathbf{R} \& \mathbf{D}$ Intensity $_{(i, t)}\left(\mathbf{R N D I}_{(i, t)}\right)$ captures the firm's overall technology development investments and innovative capacity. It is calculated as the ratio of the annual $R \& D$ investments over yearly sales. It represents an important control in the context of the current research, as this variable has been commonly used in previous literature as a measure of absorptive capacity (Zahra and George, 2002). Higher R\&D intensity may allow a firm to better search, assimilate, transform, and exploit the in-licensed technologies, and thus may influence its technology exploitation potential.

The models also control for the patenting activity of a firm, which is measured as the count of new patents registered by the firm in the observed year (Patent $\left.\operatorname{Portfolio}_{(i, t)}\left(\mathbf{P P}_{(i, t)}\right)\right)$. This variable captures a firm's innovativeness, and it is particularly important as the majority of licensed technologies are patented (Bianchi and Lejarraga, 2016).

Number of New Product Innovations $(i, t)\left(\operatorname{NNPI}_{(i, t)}\right)$ is used to measure the firm's output of its internal technology exploitation activity in the form of new product development. Also, this variable represents a key control in this study because it allows us to consider the alternative, internal path available to firms for exploiting their technologies, and so to better assess the role of in-licensing on the firm's pursuit of the external exploitation channel by the means of outlicensing. Other things being equal, a higher rate of new product development may reduce the firm's reliance on out-licensing, as the firm could primarily apply new technologies into new products.

Following Bianchi et al. (2014), the variable Manufacturing $\operatorname{Assets}_{(i, t)}\left(\mathbf{M A}_{(i, t)}\right)$ also controls for the intensity of complementary manufacturing assets in the firm, which is calculated as the ratio of the value of a firm's tangible fixed assets over total assets. This variable may influence the decision of whether a given technology should be out-licensed externally, as opposed to internally incorporated into products. The lower the manufacturing assets intensity, the more likely a firm will rely on out-licensing.

The models include also controls for firm $\operatorname{Size}_{(i, t)}$ $\left(\mathbf{S I Z E}_{(i, t)}\right)$, measured as the total number of employees in the firm, and firm $\mathbf{A g e}_{(i, t)}(\mathbf{A G E}(i, t))$, calculated as the number of years from the year of foundation of the company. Finally, industry and year dummies have also been included in all the statistical models to control for shocks and other unobservable changes related to industry- and time-specific characteristics, respectively.

\section{Methodology}

This paper aims to investigate the influence of technology in-licensing on out-licensing volume at the firm level. This section explains the methodological procedure applied.

All statistical models in this study use the same dependent variable, which is Technology Out-

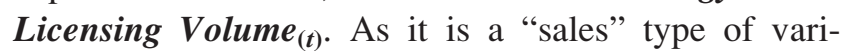
able, it is typically highly correlated with its lagged values (Arellano and Bond, 1991). Therefore, to account for this issue the lagged dependent variable among the covariates, labeled as Technology Out-

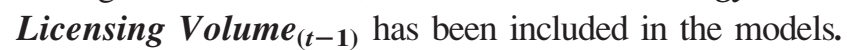
Additionally, the relationship between technology inlicensing and out-licensing may be endogenous in its nature, because a positive association between in-licensing and out-licensing might also be driven by reverse causality and unobserved heterogeneity. The out-licensing volume is closely related to unobservable characteristics, such as chief executive officer or top management team characteristics, or the technological nature of the innovation. If these unobservable characteristics also influence the propensity of a firm to in-license technology, a spurious 
correlation between in-licensing and out-licensing follows because of unobserved heterogeneity.

For these reasons, we employed a dynamic panel data approach, and more specifically a system GMM estimation procedure. The dynamic panel data approach is suitable considering that in the used panel dataset the dependent variable is autoregressive, and it is highly dependent over time. Under this condition the system GMM is the most appropriate choice. Further, the system GMM enables us to take into consideration the endogenous nature of the relationship between in-licensing and out-licensing (for a similar approach see Blundell and Bond, 1998; Colombo, Croce, and Murtinu, 2014; Grilli and Murtinu, 2015). Articles by Roodman (2009a,2009b) provided further guidance in the choices for a suitable statistical procedure. The system GMM estimation was chosen also because of the following reasons: (i) the dataset fits the criterion of "small T, large N," which means short time series and large number of firms (in the case of the final sample, $T=10$ years and $N=837$ firms); (ii) we assumed a linear functional relationship; (iii) variables included in the models are not strictly exogenous, and could be correlated with past or current realizations of the error.

All regressors (except age, year dummies, and industry dummies) are assumed endogenous. By means of system GMM, the lags of the endogenous regressors were used to control for this issue. The choice of lags is made through adjustments with the Hansen test, which has been used to assess the validity of instruments used in the models (results are reported in Table 3 ). The instrument matrix is collapsed in order to limit the number of instruments.

All six statistical models include Technology OutLicensing Volume $(t)$ as dependent variable, and a oneyear lagged value of the dependent variable (Technology Out-Licensing Volume $(t-1)$ ) in the right part of modeling equation. ${ }^{3}$ To make regression equations more understandable, each model is reported below:

- Model 1 uses the Technology In-Licensing Investments $_{(t-1)}-\operatorname{TILI}_{(i, t-1)}$ as an independent variable:

$$
\begin{aligned}
& \operatorname{TOLV}_{(i, t)}=\alpha+\beta_{1} * \operatorname{TOLV}_{(i, t-1)}+\beta_{2} * \operatorname{TILI}_{(i, t-1)} \\
+ & \gamma_{1} * \mathrm{RNDI}_{(i, t)}+\gamma_{2} * \operatorname{PP}_{(i, t)}+\gamma_{3} * \operatorname{NNPI}_{(i, t)}+ \\
+ & \gamma_{4} * \mathrm{MA}_{(i, t)}+\gamma_{5} * \operatorname{SIZE}_{(i, t)}+\gamma_{6} * \operatorname{AGE}_{(i, t)}+\eta_{(i)}+\varepsilon_{(i, t)}
\end{aligned}
$$

${ }^{3}$ This enables us to include in our models the autoregressive component of the dependent variable, and also to partially capture the effect of the out-licensing experience (investigated more in detail in Bianchi and Lejarraga, 2016).
- Model 2 uses the Technology In-Licensing Investments $_{(t-2)}-\operatorname{TILI}_{(i,} t_{-2)}$ as an independent variable:

$$
\begin{aligned}
& \operatorname{TOLV}_{(i, t)}=\alpha+\beta_{1} * \operatorname{TOLV}_{(i, t-1)}+\beta_{2} * \operatorname{TILI}_{(i, t-2)} \\
+ & \gamma_{1} * \mathrm{RNDI}_{(i, t)}+\gamma_{2} * \mathrm{PP}_{(i, t)}+\gamma_{3} * \mathrm{NNPI}_{(i, t)}+ \\
+ & \gamma_{4} * \mathrm{MA}_{(i, t)}+\gamma_{5} * \operatorname{SIZE}_{(i, t)}+\gamma_{6} * \mathrm{AGE}_{(i, t)}+\eta_{(i)}+\varepsilon_{(i, t)}
\end{aligned}
$$

- Model 3 uses the Technology In-Licensing Investments $\left._{(t-3)}-\mathrm{TILI}_{(i,} \quad t-3\right)$ as an independent variable:

$$
\begin{aligned}
& \operatorname{TOLV}_{(i, t)}=\alpha+\beta_{1} * \operatorname{TOLV}_{(i, t-1)}+\beta_{2} * \operatorname{TILI}_{(i, t-3)}+\gamma_{1} \\
& * \mathrm{RNDI}_{(i, t)}+\gamma_{2} * \operatorname{PP}_{(i, t)}+\gamma_{3} * \mathrm{NNPI}_{(i, t)}+ \\
& +\gamma_{4} * \mathrm{MA}_{(i, t)}+\gamma_{5} * \operatorname{SIZE}_{(i, t)}+\gamma_{6} * \operatorname{AGE}_{(i, t)}+\eta_{(i)}+\varepsilon_{(i, t)}
\end{aligned}
$$

- Model 4 uses the Technology In-Licensing Investments $_{(t-1)}$ TILI $_{(i,}{ }_{t-1)}, \quad$ Technology In-Licensing Investments $\left._{(t-2)}-\operatorname{TILI}_{(i,}, t-2\right)$, and Technology InLicensing Investments $(t-3)-\operatorname{TILI}_{(i, t-3)}$ as independent variables:

$$
\begin{aligned}
& \operatorname{TOLV}_{(i, t)}=\alpha+\beta_{1} * \operatorname{TOLV}_{(i, t-1)}+\beta_{2} * \operatorname{TILI}_{(i, t-1)} \\
+ & \beta_{3} * \operatorname{TILI}_{(i, t-2)}+\beta_{4} * \operatorname{TILI}_{(i, t-3)}+\gamma_{1} * \mathrm{RNDI}_{(i, t)}+ \\
+ & \gamma_{2} * \mathrm{PP}_{(i, t)}+\gamma_{3} * \operatorname{NNPI}_{(i, t)}+\gamma_{4} * \mathrm{MA}_{(i, t)}+\gamma_{5} * \operatorname{SIZE}_{(i, t)} \\
+ & \gamma_{6} * \mathrm{AGE}_{(i, t)}+\eta_{(i)}+\varepsilon_{(i, t)}
\end{aligned}
$$

- Model 5 uses the Number of Years Firm In-Licen$\operatorname{sed}_{(t)}-\mathrm{NYFIL}_{(i, t)}$ as an independent variable:

$$
\begin{gathered}
\operatorname{TOLV}_{(i, t)}=\alpha+\beta_{1} * \operatorname{TOLV}_{(i, t-1)}+\beta_{2} * \operatorname{NYFIL}_{(i, t)} \\
+\gamma_{1} * \mathrm{RNDI}_{(i, t)}+\gamma_{2} * \operatorname{PP}_{(i, t)}+\gamma_{3} * \operatorname{NNPI}_{(i, t)}+ \\
+\gamma_{4} * \mathrm{MA}_{(i, t)}+\gamma_{5} * \operatorname{SIZE}_{(i, t)}+\gamma_{6} * \operatorname{AGE}_{(i, t)}+\eta_{(i)}+\varepsilon_{(i, t)}
\end{gathered}
$$

- Model 6 uses the Firm Continuously In-Licen$\operatorname{sed}_{(t)}-\mathrm{FCIL}_{(i, t)}$ as an independent variable:

$$
\begin{gathered}
\operatorname{TOLV}_{(i, t)}=\alpha+\beta_{1} * \operatorname{TOLV}_{(i, t-1)}+\beta_{2} * \operatorname{FCIL}_{(i, t)} \\
+\gamma_{1} * \mathrm{RNDI}_{(i, t)}+\gamma_{2} * \operatorname{PP}_{(i, t)}+\gamma_{3} * \operatorname{NNPI}_{(i, t)}+ \\
+\gamma_{4} * \mathrm{MA}_{(i, t)}+\gamma_{5} * \operatorname{SIZE}_{(i, t)}+\gamma_{6} * \operatorname{AGE}_{(i, t)}+\eta_{(i)}+\varepsilon_{(i, t)}
\end{gathered}
$$

In all equations the subscripts $i$ and $t$ refer to firm and time (year), respectively; $\alpha$ represents the constant term; $\beta_{1}, \beta_{2}, \beta_{3}$, and $\beta_{4}$ are the regression coefficients 
Table 2. Product Moment Correlations and the Summary Statistics

\begin{tabular}{|c|c|c|c|c|c|c|c|c|c|c|}
\hline & 1 & 2 & 3 & 4 & 5 & 6 & 7 & 8 & 9 & 10 \\
\hline $\begin{array}{l}\text { 1. Technology } \\
\text { out-licensing } \\
\text { volume }_{(t)}\end{array}$ & 1 & & & & & & & & & \\
\hline $\begin{array}{l}\text { 2. Technology } \\
\text { in-licensing } \\
\text { investments }(t)\end{array}$ & $0.21 * * *$ & 1 & & & & & & & & \\
\hline $\begin{array}{l}\text { 3. Number of years } \\
\text { firm in-licensed }(t) \\
\text { (current, lag-1 and } \\
\text { lag-2 year) }\end{array}$ & $0.20 * * *$ & $0.93 * * *$ & 1 & & & & & & & \\
\hline $\begin{array}{l}\text { 4. Firm continuously } \\
\text { in-licensed }{ }_{(t)} \text { (current, } \\
\text { lag-1 and lag-2 year) }\end{array}$ & $0.16 * * *$ & $0.90 * * *$ & $0.93 * * *$ & 1 & & & & & & \\
\hline 5. R\&D intensity $(t)$ & $0.24 * * *$ & $0.12 * * *$ & $0.11 * * *$ & $0.08 * * *$ & 1 & & & & & \\
\hline 6. Patent portfolio ${ }_{(t)}$ & $0.35 * * *$ & $0.17 * * *$ & $0.15^{* * *}$ & $0.12 * * *$ & $0.22 * * *$ & 1 & & & & \\
\hline $\begin{array}{l}\text { 7. Number of new } \\
\text { product innovations }{ }_{(t)}\end{array}$ & $0.04 * * *$ & $0.03 * *$ & $0.03 * *$ & $0.03 * *$ & $0.09 * * *$ & -0.00 & 1 & & & \\
\hline 8. Manufacturing assets ${ }_{(t)}$ & $-0.12 * * *$ & $-0.08 * * *$ & $-0.08 * * *$ & $-0.06 * * *$ & $-0.14 * * *$ & $-0.07 * * *$ & 0.00 & 1 & & \\
\hline 9. Size ${ }_{(t)}$ & $0.23 * * *$ & $0.34 * * *$ & $0.29 * * *$ & $0.27 * * *$ & $0.14 * * *$ & $0.10^{* * *}$ & 0.02 & $-0.04 * * *$ & 1 & \\
\hline 10. $\operatorname{Age}_{(t)}$ & $0.10 * * *$ & $0.15^{* * *}$ & $0.17 * * *$ & $0.14 * * *$ & $0.09 * * *$ & $0.05 * * *$ & $0.03 * *$ & $-0.08 * * *$ & $0.13 * * *$ & 1 \\
\hline Number of observations & 7396 & 7396 & 7396 & 7396 & 7396 & 7396 & 7396 & 7396 & 7396 & 7396 \\
\hline Mean & 0.26 & 1.19 & 0.28 & 0.07 & 0.56 & 0.56 & 2.43 & 80.92 & 244.52 & 28.31 \\
\hline Standard error & 1.80 & 3.73 & 0.83 & 0.26 & 2.23 & 6.54 & 16.27 & 18.21 & 642.01 & 21.76 \\
\hline Minimum & 0 & 0 & 0 & 0 & 0 & 0 & 0 & 0 & 3 & 1 \\
\hline Maximum & 18.22 & 19.28 & 3 & 1 & 98.92 & 233 & 426 & 100 & 10,180 & 172 \\
\hline
\end{tabular}

Note that industry and year dummies are included in the analysis, but are not presented in the correlation matrix.

$* * * p$-value $<.01 ; * * p$-value $<.05$.

of the corresponding independent variables; $\gamma_{1}, \gamma_{2}, \gamma_{3}$, $\gamma_{4}, \gamma_{5}$, and $\gamma_{6}$ are the regression coefficients of the corresponding control variables; $\eta_{(i)}$ represents an unobserved individual specific effect; and $\varepsilon_{(i, t)}$ is the error term of the $i$-th cross-sectional unit.

\section{Results}

Table 2 contains descriptive statistics and correlations of the study variables. To assess the potential threat of collinearity, the variance inflation factors (VIF) were estimated. Results confirm that no VIF is greater than 6.56, which is significantly lower than the commonly used maximum VIF threshold of 10 (Hair, Anderson, Tatham, and Black, 1998; O'Brien, 2007). So, the empirical test proceeds with the dynamic panel data analysis.

Table 3 reports the results from the system GMM estimation performed, including all six models that are described in the previous section. ${ }^{4}$ All the regressions shown in Table 3 passed the Hansen tests, reassuring us about the validity of the instruments employed.

${ }^{4}$ The significance and specifications of the dummy variables are not reported, because of their marginal importance in the context of this research.
Models 1, 2, 3, and 4 test the effect of technology in-licensing investments on technology out-licensing volume (Hypothesis 1). Models 1, 2, and 3 show the influence of different time lags for in-licensing investments, separately. Model 1 displays a positive-but not significant-influence of in-licensing investments on out-licensing volume in 1-year lag. Instead, the coefficients of the 2- and 3-year lags are positive and strongly significant $(p<.01)$. Model 4 has as input all three lagged variables for technology in-licensing investments and investigates their effect on outincensing volume. This joint analysis confirms the significant positive coefficients of 2- and 3-year lag variables $(p<.1$ and $p<.01$, respectively), whereas 1 -year lag variable is still positive but not significant. To further explore the results shown in Model 4, an additional test on the joint effect of the three lagged variables related to technology in-licensing investments has been performed by the use of a Wald test on the sum of the three coefficients. The joint effect is positive $(0.255)$ and the Wald test rejects the null hypothesis that such sum is equal to 0 . All in all, the empirical results support $\mathrm{H} 1$ as they indicate a positive influence of in-licensing investments on out-licensing volume. In particular, they show the time pattern of 
Table 3. Results from the System GMM Regression

\begin{tabular}{|c|c|c|c|c|c|c|}
\hline $\begin{array}{l}\text { Dependent variable: } \\
\text { Technology out- } \\
\text { licensing volume }_{(t)}\end{array}$ & Model 1 & Model 2 & Model 3 & Model 4 & Model 5 & Model 6 \\
\hline $\begin{array}{l}\text { Technology in- } \\
\text { licensing } \\
\text { investments }_{(t-1)}\end{array}$ & $0.021(0.015)$ & & & $0.008(0.033)$ & & \\
\hline $\begin{array}{l}\text { Technology in- } \\
\text { licensing } \\
\text { investments }(t-2)\end{array}$ & & $0.049 * * *(0.016)$ & & $0.087(0.045)$ & & \\
\hline $\begin{array}{l}\text { Technology in- } \\
\text { licensing } \\
\text { investments }(t-3)\end{array}$ & & & $0.192 * * *(0.033)$ & $0.161 * * *(0.038)$ & & \\
\hline $\begin{array}{l}\text { Number of years } \\
\text { firm in-licensed } \\
(t)\end{array}$ & & & & & $0.157 * *(0.063)$ & \\
\hline $\begin{array}{l}\text { Firm continuously } \\
\text { in-licensed }_{(t)}\end{array}$ & & & & & & $1.014 * * *(0.228)$ \\
\hline $\mathrm{R} \& \mathrm{D}$ intensity $(t)$ & $0.090 * * *(0.011)$ & $0.060 * * *(0.014)$ & $0.184 * * *(0.030)$ & $0.173 * * *(0.041)$ & $0.041 * * *(0.009)$ & $0.023(0.012)$ \\
\hline Patent portfolio $_{(t)}$ & $0.057 * * *(0.002)$ & $0.045 * * *(0.002)$ & $0.055 * * *(0.004)$ & $0.053 * * *(0.004)$ & $0.050 * * *(0.002)$ & $0.045 * * *(0.002)$ \\
\hline $\begin{array}{l}\text { Number of new } \\
\text { product } \\
\text { innovations }_{(t)}\end{array}$ & $-0.001(0.001)$ & $-0.001(0.002)$ & $0.004(0.003)$ & $0.004(0.004)$ & $0.000(0.002)$ & $-0.001(0.001)$ \\
\hline $\begin{array}{l}\text { Manufacturing } \\
\operatorname{assets}_{(t)}\end{array}$ & $-0.001(0.002)$ & $-0.002(0.002)$ & $-0.001(0.006)$ & $-0.002(0.007)$ & $-0.002(0.002)$ & $-0.002(0.003)$ \\
\hline $\operatorname{Size}_{(t)}$ & $0.000(0.000)$ & $0.001 * *(0.000)$ & $-0.000(0.000)$ & $-0.000(0.000)$ & $0.001 * * *(0.000)$ & $0.001 * * *(0.000)$ \\
\hline $\operatorname{Age}_{(t)}$ & $0.000(0.001)$ & $-0.001(0.001)$ & $-0.003(0.002)$ & $-0.005(0.003)$ & $-0.001(0.001)$ & $-0.003(0.001)$ \\
\hline $\begin{array}{l}\text { Technology out- } \\
\text { licensing } \\
\text { volume }_{(t-1)}\end{array}$ & $0.414 * * *(0.017)$ & $0.390 * * *(0.023)$ & $0.137 * * *(0.035)$ & $0.134 * *(0.055)$ & $0.402 * * *(0.025)$ & $0.421 * * *(0.026)$ \\
\hline $\begin{array}{l}\text { Year effects (year } \\
\text { dummies) }\end{array}$ & Included & Included & Included & Included & Included & Included \\
\hline $\begin{array}{l}\text { Industry effects } \\
\text { (industry } \\
\text { dummies) }\end{array}$ & Included & Included & Included & Included & Included & Included \\
\hline Number of groups & 837 & 837 & 837 & 837 & 837 & 837 \\
\hline $\begin{array}{l}\text { Number of } \\
\text { observations }\end{array}$ & 7396 & 6576 & 5752 & 5732 & 7396 & 7396 \\
\hline $\begin{array}{l}\text { Number of } \\
\text { instruments }\end{array}$ & 83 & 81 & 79 & 80 & 81 & 81 \\
\hline Hansen & 46.75 & 48.45 & 33.03 & 32.53 & 45.41 & 44.36 \\
\hline
\end{tabular}

Notes: Standard errors in parentheses next to coefficient estimates. Constant terms included in the estimates (coefficients omitted in the table). Estimates are derived from the two-step system GMM estimator with finite sample correction (Windmeijer, 2005). Hansen is the test of the validity of the overidentifying restrictions based on the efficient two-step system GMM estimator. Moment conditions of endogenous variables start from $t-3$ $(t-2)$ for instruments in levels (differences). AR1 and AR2 tests confirm the presence of first-order serial correlation, but exclude second-order serial correlation, respectively (tests omitted in the table).

$* * * p$-value $<.01 ; * * p$-value $<.05$.

the effects of in-licensing investments on out-licensing volume, with investments made in the preceding two years playing significant influence on the amount of revenues that a firm earns through technology outlicensing. This positive effect is stronger when considering the in-licensing investments made three years before.

Models 5 and 6 examine the influence of technology in-licensing experience on technology out-licensing volume, as stated in H2. Model 5 includes as independent variable the count of years in which the firm has in- licensed technologies. The regression coefficient for this variable is positive and significant $(p<.05)$. Model 6 presents as independent variable the dummy indicating whether a firm has continuously in-licensed technology in a three-year window. The regression coefficient for this variable is positive and strongly significant $(p<.01)$. So, both models find that a firm's prior inlicensing experience has a significant positive effect on out-licensing volume, thus supporting $\mathrm{H} 2$.

As regards controls, they show a positive and significant effect for firm's R\&D intensity and patent 
portfolio on out-licensing volume throughout all the six models.

Finally, with respect to the dynamic nature of the employed panel dataset, the coefficient of the 1-year lagged technology out-licensing volume is always positive and significant $(p<.01)$, as expected.

\section{Robustness Checks}

To test the robustness of the above findings three different sets of checks are performed. First, according to the approach of Bianchi and Lejarraga (2016) a further model including the workforce's skills as an additional control variable has been tested. As they show that advanced skills of workforce positively impact the out-licensing performance, this could potentially influence also the results. Obtained results are consistent with those presented in Table 3 (results are available upon request from the authors).

Second, as only the firms that report their outlicensing revenues in at least 9 of the 10 years between 1998 and 2007 were included in the final sample, this may generate a problem of sample selection bias. To test for the existence of a sample selection bias, Wooldridge's (1995) variable addition test has been applied, following the methodology proposed by Semykina and Wooldridge (2006), which is appropriate in the presence of unobserved heterogeneity and endogenous regressors. The first step consisted of estimating a probit model on companies reporting or not reporting their revenues from technology out-licensing. ${ }^{5}$ In the second step, the estimated coefficients of this first model were used to obtain the inverse Mill's ratio control factor for all firms that constitute the dataset's overall population. Finally, this time-varying ratio was inserted in the main system GMM regressions as a variable controlling for the unobserved heterogeneity that affects a firm's probability of being sampled. ${ }^{6}$ The results for all the models indicate that inverse Mill's ratio coefficients are not statistically significant, meaning that no remarkable sample selection bias exists in the analysis, therefore firms reporting licensing revenues do not significantly differ from the others. Moreover, the inclusion of the inverse Mill's ratios does not significantly influence the main results

\footnotetext{
${ }^{5}$ Dependent variable in this model is the binary variable taking value 1 if the company reports out-licensing revenues, and value 0 if it does not. Independent variables for the probit sample-selection model are variables that describe general firm characteristics (size, age, industry, and R\&D intensity) and a dummy variable capturing whether the firm reported the amount of in-licensing investments or not. ${ }^{6} \mathrm{~A}$ similar methodology has been applied in the papers by Colombo, Grilli, Murtinu, Piscitello, and Piva (2009) and Colombo et al. (2014).
}

of this study, which remain in line with the main ones presented in Table 3 (results are available upon request from the authors).

Finally, the main system GMM regressions were replicated on the SBSS sample of 2014 firms between the time period 1998-2007, following Bianchi and Lejarraga (2016). This enables also to relax the conservative approach used to build the sample for the main analyses discussed in the previous section. The results are in line with the main findings presented in Table 3 (results are available upon request from the authors).

\section{Discussion and Conclusion}

This study empirically investigates the influence of technology inflows on technology outflows, two key components of the OI model. Particularly, it focuses on licensing as a main contractual form for OI, and shows that larger investments in in-licensing and more extensive in-licensing experience drive superior volume of technology out-licensing.

This paper has implications for research into OI and licensing, primarily. With regard to OI, the study offers a holistic perspective on the OI paradigm, integrating inbound and outbound approaches. While such a perspective is common in theoretical OI articles, it has not been so in empirical studies, which have typically focused on either the inward (Laursen and Salter, 2006) or the outward dimension of the model (Bianchi et al., 2010). The results about the positive relationship between in-licensing and out-licensing suggest that there is a need for jointly observing inbound and outbound OI processes, and it provides empirical support to the concept of coupled OI process, which has been proposed by Enkel et al. (2009) but limitedly tested.

The positive influence that in-licensing exerts on out-licensing volume supports the results by Lichtenthaler (2008) and van de Vrande (2009), who find that firms opening up their innovation processes tend to do so in both directions. The balanced open innovators mentioned in these studies are those organizations that actively engage in both external technology acquisition and commercialization, which means that they adopt coupled OI processes. Their approach may derive from an integrated technology strategy that is open to the innovation opportunities offered by the external environment (Chesbrough, 2003).

The positive relationship between in-licensing and out-licensing is observed despite the phenomenon 
described by some scholars, according to whom more intense acquisition of external technologies may reduce the external technology commercialization potential of the firm. The logic is that in order to earn higher margins from its R\&D activities and avoid acting as a mere innovation intermediary, technology acquired from external sources should be exploited internally (also, clauses in the in-licensing contract may prohibit the firm to out-license the in-licensed technology). Similarly, to realize out-licensing opportunities, it is desirable to create the related technology internally. While these effects may occur at the level of a single technology, they do not seem to play a role at the firm level. Instead, the presented empirical analysis suggests that firms adopting OI might act as technology brokers in their industrial networks, by actively managing their portfolio of in-licensing and outlicensing deals (Walter, 2012).

By considering in-licensing experience, this study advances the capability-based understanding of technology transactions. Consistent with the OI paradigm, which assumes complementarity between technology inflows and outflows, this paper provides evidence that in-licensing experience positively influences the volume of technology out-licensing. This result informs the vibrant OI debate by supporting the existence of synergies in the development of absorptive and desorptive capacities. This evidence therefore complements existing anecdotal evidence of firms, like in the case of Lucent (Amesse and Cohendet, 2001), that, by engaging in bi-directional technology transfers, achieve a co-evolution of absorptive and desorptive capacity and their mutual reinforcement. The fact that absorptive and desorptive capacities go hand in hand may support the conceptual framework developed by Lichtenthaler and Lichtenthaler (2009), according to which these two capacities, together with inventive, transformative, connective, and innovative capacities, are critical components of a firm's ability to manage internal and external technology in OI processes.

In particular, the longitudinal nature of this study offers evidence for the process model of absorptive capacity (Jansen, Van Den Bosch, and Volberda, 2005; Lane et al., 2006; Todorova and Durisin, 2007). The process model of absorptive capacity depicts how external technology inflow is absorbed by the companies in stages. This view proposes that there exists a time gap before the technology inflow resonates on the technology exploitation outputs. This time gap exists because external technology first needs to be recognized and understood, then assimilated and trans- formed, before it can be applied. External technology goes under three types of learning throughout this process-exploratory learning, transformative learning, and exploitative learning (Lane et al., 2006). This work supports this, as it shows that recent technology in-licensing investments do not have any influence on the current out-licensing volume, however former technology intakes and experience with inbound technology transfers have a significant and positive influence that even becomes more significant as the focus shifts from a 2-year to a 3-year time gap.

From an empirical point of view, the use of a "distributed lags" procedure to study the effects of inlicensing investments on out-licensing volume represents another contribution of this study. Few researchers in OI research have used this methodological approach (Ahuja and Katila, 2001), notwithstanding the long duration of innovation processes and the existence of significant delays between causes and their effects. The analysis of this study shows that the influence played by the technology acquired through inlicensing on out-licensing revenues has a positive effect after a certain period of time (i.e., two years), and that this effect becomes stronger as the time passes (i.e., three years). However, this does not mean that this effect does not diminish in a longer time window (as knowledge decay perspective proposes). However, as the dataset is limited to 10 years of observations, it limits the possibility to track the influence of longer time gaps. This is consistent with the idea that external technology acquired through inlicensing should be absorbed by the firm and adapted to the existing technology and routines, in order to incorporate it into operations and exploit it (Jansen et al., 2005; Zahra and George, 2002).

This paper also contributes to the growing body of research on technology licensing, which is a practice that is gaining relevance in firms' corporate strategies as a way to exploit technology assets, which is complementary or alternative to internal new product development. In particular, the results of this paper inform the debate on the determinants of out-licensing volume. While prior studies (Bianchi, Cavaliere, et al., 2011; Bianchi, Chiaroni, et al., 2011; Lichtenthaler and Ernst, 2007) have examined different factorsfrom organizational (like the establishment of a dedicated function to licensing) to human (like the scientific skills of the licensing managers), from resource based (like the marketing resources of a firm) to process based (like the systematic nature of the licensing process) - this is one of the first studies to explore the 
role of in-licensing related determinants, such as the amount of investments and cumulated experience, on the out-licensing volume. The presented empirical analysis shows that, even if the same contractual form is executed in the opposite direction, it is beneficial to increase the volume of out-licensing, as a consequence of resource-based and capabilities effects. By exploring the effects of in-licensing experience on outlicensing revenues, this paper complements previous studies that have examined the role of different types of experience, both task-specific and partner-specific, on out-licensing volume (Anand and Khanna, 2000; Kim and Vonortas, 2006), and out-licensing experience (Bianchi and Lejarraga, 2016). The current study adds to these a supplementary type of experience, which is gained by performing a largely similar process but in the opposite direction.

Finally, the paper also contributes to the growing literature on market for technologies and ideas (for a review, see Natalicchio et al., 2014). In particular, the positive effects of technology inflows on outflows suggest-as a promising future research direction-to investigate whether and under what conditions knowledge seekers with extensive experience in markets for technology will be more likely to participate in these markets as knowledge owners or solvers. This will help improve the understanding of the complex dynamics characterizing markets for technologies.

\section{Managerial Implications}

This study holds interesting implications for managers. First, it highlights the positive impact that investments to in-license technologies have on the volume of outlicensing. The presented empirical results suggest that in-licensing contributes to a richer and more valuable technology base, which translates into higher revenues from out-licensing. Managers attempting to increase revenues from out-licensing should not focus only on the internal creation of new technologies but also on the acquisition of technology from external sources, which can then be combined with internal resources and generate lucrative resource configurations. Second, the study informs managers that by increasing their external technology acquisition activities, they will likely increase their external technology commercialization volume as well. In other words, the adoption of the OI paradigm is likely to occur in both dimensions, which allows for leveraging the complementarities between technology inflows and outflows. The finding that in-licensing experience has a positive influence on out-licensing, and so that absorptive and desorptive capacities may largely overlap, is good news for managers as it may facilitate the transition from a closed innovation approach to an OI one. Finally, managers should not expect immediate benefits in their outlicensing business from intensely buying external technologies. In fact, it could take at least three years before in-licensing investments pay off. Similarly, managers are warned about the existence of technology depreciation, which reduces the out-licensing potential over time.

\section{Limitations and Future Research}

Some limitations of this study are worth noting. The present work takes as level of analysis the firm, exploring the influence of the overall in-licensing investments and experience on the total out-licensing volume. Future research should analyze this relationship at a technology or project level to assess whether some complementarities between technologies inflows and outflows exist at this level of analysis. The variable for in-licensing investments gives an aggregate indication of the value of the acquired technologies, but it does not provide information about their stage of development or their relatedness with internal technological resources. Moreover, the variable used to capture in-licensing experience does not distinguish between firms that have executed many or few deals within each year. This aggregate measure, due to a limitation of the dataset, also does not enable us to distinguish between prior transactions undertaken with the same or different partners.

Additionally, this paper has not considered how contextual factors may influence the relationships here investigated. Differences among firms may be substantial: in-licensing and out-licensing may be positively related in firms with highly diversified technology portfolios, but this may not be true for technology specialist firms. Also the workforce characteristics and their skills may act as a moderator, as shown by Bianchi and Lejarrage (2016) in the relationship between out-licensing experience and licensing revenues. Examining the moderating effects of these contextual factors could be an interesting extension of this study.

An additional limitation of the dataset that has not been mentioned in the paper is the lack of crossnational comparison. ${ }^{7}$ Nevertheless, as recognized by Un (2015), innovation systems have different

\footnotetext{
${ }^{7}$ The authors are grateful to an anonymous reviewer for this suggestion.
} 
characteristics across countries, and this heterogeneity should play a role in determination of firms' approach to OI and management of in-licensing and outlicensing flows. Further studies can analyze whether firms' geographical origins (and locations), distinguishing for example between emerging and advanced countries, impact the relationship between in-licensing and out-licensing. These geographical characteristics were not studied because of data limitation.

Finally, in this paper it has not been possible to study how the relationship between in-licensing and out-licensing may depend also on the characteristics of the acquired technology, such as radicalness, generality, novelty, and relatedness with the firm's technological portfolio. ${ }^{8}$ Further studies should analyze the moderating (or mediating) effect of the characteristics of the externally sources technology on the role played by in-licensing activities in dynamically affecting outlicensing strategies and performance.

\section{References}

Ahuja, G., and R. Katila. 2001. Technological acquisitions and the innovation performance of acquiring firms: A longitudinal study. Strategic Management Journal 22 (3): 197-220.

Amesse, F., and P. Cohendet. 2001. Technology transfer revisited from the perspective of the knowledge-based economy. Research Policy 30 (9): 1459-78.

Anand, B. N., and T. Khanna. 2000. Do firms learn to create value? The case of alliances. Strategic Management Journal 21: 295-315.

Arellano, M., and S. Bond. 1991. Some tests of specification for panel data: Monte Carlo evidence and an application to employment equations. The Review of Economic Studies 58 (2): 277-97.

Arora, A., A. Fosfuri, and A. Gambardella. 2001. Markets for technology: The economics of innovation and corporate strategy. Cambridge, MA: The MIT Press.

Arora, A., and A. Gambardella. 2010. Ideas for rent: An overview of markets for technology. Industrial and Corporate Change 19 (3): 775-803.

Athreye, S., and J. Cantwell. 2007. Creating competition? Globalisation and the emergence of new technology producers. Research Policy 36: 209-26.

Atuahene-Gima, K. 1993. Inward technology licensing as an alternative to internal R\&D in new product development: A conceptual framework. Journal of Product Innovation Management 9 (2): 156-67.

Barney, J. 1991. Firm resources and sustained competitive advantage. Journal of Management 17 (1): 99-120.

Beneito, P. 2003. Choosing among alternative technological strategies: An empirical analysis of formal sources of innovation. Research Policy 32: 693-713.

Beneito, P. 2006. The innovative performance of in-house and contracted R\&D in terms of patents and utility models. Research Policy 35 (4): 502-17.

Bianchi, M., S. Campodall'Orto, F. Frattini, and P. Vercesi. 2010. Enabling open innovation in SMEs: How to find alternative applications for your technologies. $R \& D$ Management 40: 463-80.

\footnotetext{
${ }^{8}$ The authors are grateful to an anonymous reviewer for this suggestion.
}

Bianchi, M., A. Cavaliere, D. Chiaroni, F. Frattini, and V. Chiesa 2011. Organizational modes for open innovation in the biopharmaceutical industry: An exploratory analysis. Technovation 31 (1): 22-33.

Bianchi, M., D. Chiaroni, V. Chiesa, and F. Frattini. 2011. Exploring the role of human resources in technology licensing: An empirical analysis of biotech new technology-based firms. Technology Analysis and Strategic Management 23 (8): 825-49.

Bianchi, M., A. Croce, C. Dell'Era, C. A. Di Benedetto, and F. Frattini. 2015. Organizing for inbound open innovation: How external consultants and a dedicated R\&D unit influence product innovation performance. Journal of Product Innovation Management 33: 492510.

Bianchi, M., F. Frattini, J. Lejarraga, and A. Di Minin. 2014. Technology exploitation paths: Combining technological and complementary resources in new product development and licensing. Journal of Product Innovation Management 31: 146-69.

Bianchi, M., and J. Lejarraga. 2016. Learning to license technology: The role of experience and workforce's skills in Spanish manufacturing firms. $R \& D$ Management, doi:10.1111/radm.12211.

Bidault, F., and W. A. Fischer. 1994. Technology transactions-networks over markets. $R \& D$ Management 24: 373-86.

Blundell, R., and S. Bond. 1998. Initial conditions and moment restrictions in dynamic panel data models. Journal of Econometrics 87: 115-43.

Brown, B., and S. D. Anthony. 2011. How P\&G tripled its innovation success rate. Harvard Business Review 89 (6): 64-72.

Capaldo, A., and A. Messeni Petruzzelli. 2011. In search of alliancelevel relational capabilities: Balancing innovation value creation and appropriability in R\&D alliances. Scandinavian Journal of Management 27 (3): 273-86.

Capaldo, A., and A. Messeni Petruzzelli. 2015. Origins of knowledge and innovation in R\&D alliances: A contingency approach. Technology Analysis \& Strategic Management 27 (4): 461-83.

Cassiman, B., and G. Valentini. 2015. Open innovation: are inbound and outbound knowledge flows really complementary? Strategic Management Journal, doi:10.1002/smj.2375.

Chesbrough, H. 2003. Open innovation. Boston, MA: Harvard Business School Press.

Chesbrough, H. 2006. Open innovation: A new paradigm for understanding industrial innovation. In Open innovation: Researching a new paradigm, ed. H. Chesbrough, W. Vanhaverbeke, and J. West, 1-12. Oxford, UK: Oxford University Press.

Coff, R. 2003. Bidding wars over R\&D-intensive firms: Knowledge, opportunism, and the market for corporate control. Academy of Management Journal 46: 74-85.

Cohen, W. H., and D. A. Levinthal. 1990. Absorptive capacity: A new perspective on learning and innovation. Administrative Science Quarterly 35 (1): 128-52.

Colombo, M.G., A. Croce, and S. Murtinu. 2014. Ownership structure, horizontal agency costs and the performance of high-tech entrepreneurial firms. Small Business Economics 42 (2): 265-82.

Colombo, M. G., L. Grilli, S. Murtinu, L. Piscitello, and E. Piva. 2009. Effects of international R\&D alliances on performance of high-tech start-ups: A longitudinal analysis. Strategic Entrepreneurship Journal 3: 346-68.

Easterby-Smith, M., M. A. Lyles, and E. W. K. Tsang. 2008. Interorganizational knowledge transfer: Current themes and future prospects. Journal of Management Studies 45 (4): 677-90.

Enkel, E., O. Gassmann, and H. Chesbrough. 2009. Open R\&D and open innovation: Exploring the phenomenon. $R \& D$ Management 39 (4): $311-16$

Fiol, C. M., and M. A. Lyles. 1985. Organizational learning. Academy of Management Review 10: 803-13. 
Flemming, L., and O. Sorenson, 2004. Science as a map in technological search. Strategic Management Journal 25: 909-28.

Gambardella, A., P. Giuri, and A. Luzzi. 2007. The market for patents in Europe. Research Policy 36: 1163-83.

Ganesan, S., A. J. Malter, and A. Rindfleisch. 2005. Does distance still matter? Geographic proximity and new product development. Journal of Marketing 69: 44-60.

Granstrand, O. 2004. The economics and management of technology trade: Towards a pro-licensing era? International Journal of Technology Management 27 (2/3): 209-40.

Grant, R. M. 1996. Prospering in dynamically-competitive environments: Organizational capability as knowledge integration. Organization Science 7 (4): 375-87.

Griffith, R., Huergo, E., Mairesse, J., and Peters, B. 2006. Innovation and productivity across four European countries. Oxford Review of Economic Policy 22 (4): 483-98.

Grilli, L., and S. Murtinu. 2015. New technology-based firms in Europe: Market penetration, public venture capital, and timing of investment. Industrial and Corporate Change 24 (5): 1109-48.

Grindley, P. C., and D. J. Teece. 1997. Managing intellectual capital: Licensing and cross-licensing in semiconductors and electronics. California Management Review 39 (2): 8-41.

Guadamuz, A. L. 2005. The future of technology transfer in the global village. Journal of World Intellectual Property 3 (4): 589-602.

Hair, J. F., R. E. Anderson, R. L. Tatham, and W. C. Black. 1998. Multivariate data analysis. Upper Saddle River, NJ: Prentice-Hall.

Henderson, R., and I. Cockburn. 1996. Scale, scope, and spillovers: The determinants of research productivity in drug discovery. The RAND Journal of Economics 27 (1): 32-59.

Hoang, H., and F. T. Rothaermel. 2005. The effect of general and partner-specific alliance experience on joint $R \& D$ project performance. Academy of Management Journal 48: 332-45.

Hung, K. -P., and C. Chou. 2013. The impact of open innovation on firm performance: The moderating effects of internal $R \& D$ and environmental turbulence. Technovation 33 (10-11): 1-13.

Jacobides, M. G., and S. G. Winter. 2005. The co-evolution of capabilities and transaction costs: Explaining the institutional structure of production. Strategic Management Journal 26 (5): 395-413.

Jansen, J. J. P., F. A. J. Van Den Bosch, and H. W. Volberda. 2005. Managing potential and realized absorptive capacity: How do organizational antecedents matter? Academy of Management Journal 48 (6): 999-1015.

Jiang, X., and Y. Li. 2009. An empirical investigation of knowledge management and innovative performance: The case of alliances. Research Policy 38: 358-68.

Kim, Y. J., and N. S. Vonortas. 2006. Technology licensing partners. Journal of Economics and Business 58 (4): 273-89.

Kogut, B., and U. Zander. 1992. Knowledge of the firm, combinative capabilities, and the replication of technology. Organization Science 3 (3): 383-97.

Kotlar, J., A. De Massis, F. Frattini, M. Bianchi, and H. Fang. 2013. Technology acquisition in family and nonfamily firms: A longitudinal analysis of Spanish manufacturing firms. Journal of Product Innovation Management 30: 1073-88

Lane, P. J., B. R. Koka, and S. Pathak. 2006. The reification of absorptive capacity: A critical review and rejuvenation of the construct. Academy of Management Review 31 (4): 833-63.

Lane, P. J., and M. Lubatkin. 1998. Relative absorptive capacity and interorganizational learning. Strategic Management Journal 19: 461-77.

Laursen, K., M. I. Leone, and S. Torrisi. 2010. Technological exploration through licensing: New insights from the licensee's point of view. Industrial and Corporate Change 19 (3): 871-97.
Laursen, K., and A. Salter. 2006. Open for innovation: The role of openness in explaining innovation performance among U.K. manufacturing firms. Strategic Management Journal 27 (2): 131-50.

Leone, M. I., and T. Reichstein. 2012. Licensing-in fosters rapid invention! The effect of the grant-back clause and technological unfamiliarity. Strategic Management Journal 33 (8): 965-85.

Levinthal, D. A., and J. G. March. 1993. Exploration and exploitation in organizational learning. Strategic Management Journal 14: 95112 .

Levitt, B., and J. March. 1988. Organizational learning. Annual Review of Sociology 14: 319-40.

Lichtenthaler, U. 2005. External commercialization of knowledge: Review and research agenda. International Journal of Management Reviews 7 (4): 231-55.

Lichtenthaler, U. 2008. Open innovation in practice: An analysis of strategic approaches to technology transactions. IEEE Transactions on Engineering Management 55 (1): 148-57.

Lichtenthaler, U. 2011. Open innovation: Past research, current debates, and future directions. Academy of Management Perspectives 25 (1): $75-93$.

Lichtenthaler, U., and H. Ernst. 2007. Developing reputation to overcome the imperfections in the markets for knowledge. Research Policy 36: 37-55.

Lichtenthaler, U., and E. Lichtenthaler. 2009. A capability-based framework for open innovation: Complementing absorptive capacity. Journal of Management Studies 46 (8): 1315-38.

Lichtenthaler, U., and E. Lichtenthaler. 2010. Technology transfer across organizational boundaries: Absorptive capacity and desorptive capacity. California Management Review 53 (1): 154-70.

Lilien, G. L., P. D. Morrison, K. Searls, M. Sonnack, and E. von Hippel. 2002. Performance assessment user of the lead process new for product development. Management Science 48 (8): 1042-59.

Lowe, J., and P. Taylor. 1998. R\&D and technology purchase through license agreements: Complementary strategies and complementary assets. $R \& D$ Management 28: 263-78.

Markman, G. D., M. I. Espina, and P. H. Phan. 2004. Patents as surrogates for inimitable and non-substitutable resources. Journal of Management 30: 529-44.

Markman, G. D., P. T. Gianiodis, P. H. Phan, and D. B. Balkin. 2005. Innovation speed: Transferring university technology to market. Research Policy 34 (7): 1058-75.

Mowery, D. C., J. E. Oxley, and B. S. Silverman. 1996. Strategic alliances and inter-firm knowledge transfer. Strategic Management Journal 17: 77-91.

Natalicchio, A., A. M. Petruzzelli, and A. C. Garavelli. 2014. A literature review on markets for ideas: Emerging characteristics and unanswered questions. Technovation 34: 65-76.

O'Brien, R. M. 2007. A caution regarding rules of thumb for variance inflation factors. Quality \& Quantity 41: 673-90.

Reuer, J. J., and N. Lahiri. 2014. Searching for alliance partners: Effects of geographic distance on the formation of $\mathrm{R} \& \mathrm{D}$ collaborations. Organization Science 25: 283-98.

Rigby, D., and C. Zook. 2002. Open market innovation. Harvard Business Review 80: 80-89.

Roberts, E. B., and C. A. Berry. 1984. Entering new business: Selecting strategies for success. MIT Sloan Management Review 26: 1-34.

Roodman, D. 2009a. A note on the theme of too many instruments. Oxford Bulletin of Economics and Statistics 71 (1): 135-58.

Roodman, D. 2009b. How to do xtabond2: An introduction to difference and system GMM in Stata. The Stata Journal 9 (1): 86-136.

Sampson, R. C. 2005. Experience effects and collaborative returns in R\&D alliances. Strategic Management Journal 26 (11): 1009-31. 
Sampson, R. C. 2007. R\&D alliances and firm performance: The impact of technological diversity and alliance organization on innovation. Academy of Management Journal 50: 364-86.

Schilling, M. A., and H. K. Steensma. 2002. Disentangling the theories of firm boundaries: A path model and empirical test. Organization Science 13 (4): 387-401.

Semykina, A., and J. M. Wooldridge. 2006. Estimating panel data models in the presence of endogeneity and selection: Theory and application. Working paper. East Lansing, MI: Michigan State University.

Stuart, T. E. 2000. Interorganizational alliances and the performance of firms: A study of growth and innovation rates in a high-technology industry. Strategic Management Journal 21: 791-811.

Stuart, T. E., S. Z. Ozdemir, and W. W. Ding. 2007. Vertical alliance networks: The case of university-biotechnology-pharmaceutical alliance chains. Research Policy 36: 477-98.

Teece, D. J., G. Pisano, and A. Shuen. 1997. Dynamic capabilities and strategic management. Strategic Management Journal 18: 509-33.

Todorova, G., and B. Durisin. 2007. Absorptive capacity: Valuing a reconceptualization. The Academy of Management Review 32 (3): 77486.

Tushman, M. L., and P. Anderson. 1986. Technological discontinuities and organizational environments. Administrative Science Quarterly 31 (3): 439-65.
Un, C. A. 2015. The liability of localness in innovation. Journal of International Business Studies 47: 44-67.

Uzzi, B. 1997. Social structure and competition in interfirm networks: The paradox of embeddedness. Administrative Science Quarterly 42: $35-67$.

van de Vrande, V., J. P. J. de Jong, W. Vanhaverbeke, and M. de Rochemont. 2009. Open innovation in SMEs: Trends, motives and management challenges. Technovation 29: 423-37.

von Hippel, E. 1986. Lead users: A source of novel product concepts. Management Science 32: 791-805.

Walter, J. 2012. The influence of firm and industry characteristics on returns from technology licensing deals: Evidence from the US computer and pharmaceutical sectors. $R \& D$ Management 42: 435-54.

Wooldridge, J. M. 1995. Selection corrections for panel data models under conditional mean independence assumptions. Journal of Econometrics 68: 115-32.

Windmeijer, F. 2005. A finite sample correction for the variance of linear efficient two-step GMM estimators. Journal of Econometrics 126 (1): $25-51$.

Woznick, A. 1996. A basic guide to exporting. San Rafael, CA: World Trade Press.

Zahra, S. A., and G. George. 2002. Absorptive capacity: A review, reconceptualization, and extension. Academy of Management Review 27 (2): 185-203. 